\title{
Evaluation of galectins 1 and 3 expression in canine melanoma $^{1}$
}

\author{
Jéssica S. Garcia²* (D), Nicolle G.T.Q. Hazarbassanov², Júlia C. Nakamura ${ }^{3}$, \\ Victor Nowosh ${ }^{3}$, Bruno Cogliati ${ }^{4}$, Lilian Rose Marques de Sá ${ }^{4}$ \\ and Cristina O. Massoco ${ }^{4}$
}

\begin{abstract}
Garcia J.S., Hazarbassanov N.G.T.Q., Nakamura J.C., Nowosh V., Cogliati B., Marques de Sá L.R. \& Massoco C.O. 2020. Evaluation of galectins 1 and 3 expression in canine melanoma. Pesquisa Veterinária Brasileira 40(12):1010-1017. Departamento de Patologia, Faculdade de Medicina Veterinária e Zootecnia, Universidade de São Paulo, Avenida Prof. Dr. Orlando Marques de Paiva 87, Cidade Universitária, São Paulo, SP 05508-270, Brazil. E-mail: jessica.sg@hotmail.com

Canine melanoma is a frequently-occuring neoplasm in dogs and presents as malignant and highly metastatic in this context, studies that contribute to the understanding of the tumor microenvironment in melanoma include the role of galectins. Galectins are proteins of the family of animal lectins that display carbohydrate recognition domains. Galectin-1 and galectin-3 are associated with neoplastic transformation, neoplastic cell survival, angiogenesis, immune system evasion, and metastasis. The goal of this study was to establish a correlation between expression patterns of galectin- 1 and galectin- 3 and the different degrees of aggressiveness of canine melanoma, as well as to determine serum concentration of galectin-3 in dogs with melanoma. Galectin-1 and galectin-3 expression was analyzed by immunohistochemistry in 30 canine melanomas, six melanocytomas and nine metastatic lymph nodes from patients whose primary tumors were also processed and analyzed. Serum samples from 30 dogs were collected and galectin-3 concentration was determined by ELISA and compared to the samples of 10 healthy dogs. Canine melanoma samples expressed galectin- 1 in the cytoplasm and presented a variable pattern of galectin-3 staining depending on melanoma aggressiveness. We observed a decrease in the percentage of cells with cytoplasmic galectin-3 immunolabeling simultaneous to the increased nuclear staining intensity, while there was also a decrease in the percent frequency of nuclear galectin-3 immunolabeled cells according to progression of melanoma, comparing the least to the most aggressive cases. Dogs with melanoma had increased serum levels of galectin-3 when compared to healthy animals, suggesting its potential biomarker of patients with melanoma.
\end{abstract}

INDEX TERMS: Galectin-1, galectin-3, canine, melanoma, lectins, neoplasms, immunohistochemistry, tumor microenvironment, dogs.

\footnotetext{
${ }^{1}$ Received on October 29, 2019.

Accepted for publication on August 28, 2020.

Master's research of the first author with support from CAPES and FAPESP.

${ }^{2}$ Departamento de Patologia, Faculdade de Medicina Veterinária e Zootecnia (FMVZ), Universidade de São Paulo (USP), Avenida Prof. Dr. Orlando Marques de Paiva 87, Cidade Universitária, São Paulo, SP 05508270, Brazil. *Corresponding author: jessica.sg@hotmail.com

${ }^{3}$ Graduate Program, Departamento de Patologia, Faculdade de Medicina Veterinária e Zootecnia (FMVZ), Universidade de São Paulo (USP), Avenida Prof. Dr. Orlando Marques de Paiva 87, Cidade Universitária, São Paulo, SP 05508-270, Brazil.

${ }^{4}$ Professor, Departamento de Patologia, Faculdade de Medicina Veterinária e Zootecnia (FMVZ), Universidade de São Paulo (USP), Avenida Prof. Dr. Orlando Marques de Paiva 87, Cidade Universitária, São Paulo, SP 05508-270, Brazil.
}

RESUMO.- [Avaliação da expressão das galectinas 1 e 3 no melanoma canino.] 0 melanoma canino é uma neoplasia frequente em cães que apresenta um potencial maligno e metastático. Neste contexto, investigar o microambiente tumoral é fundamental para compreender os mecanismos intercelulares e intracelulares envolvidos no desenvolvimento e progressão da doença. Neste estudo, destacamos as galectinas, proteínas da família das lectinas animais que exibem domínios de reconhecimento à carboidratos; a galectina-1 e a galectina-3 estão associadas a transformação neoplásica, sobrevivência de células neoplásicas, angiogênese, evasão do sistema immune e desenvolvimento de metástases. 0 objetivo deste estudo foi 
determinar os padrões de expressão de galectina-1 e galectina-3 em diferentes graus de agressividade do melanoma canino, bem como dosar a concentração sérica de galectina-3 em cães com melanoma e comparar com cães saudáveis. A expressão de galectina-1 e galectina-3 foi analisada em 30 melanomas caninos, seis melanocitomas e nove linfonodos metastáticos. A galectina-3 sérica foi mensurada em 30 cães com melanoma e comparada a 10 cães saudáveis. No melanoma canino a expressão de galectina-1 foi citoplasmática e a expressão de galectina-3 foi variável de acordo com o grau de agressividade. Notou-se uma redução na porcentagem de células com imunomarcação de galectina-3 citoplasmática e um aumento simultâneo da intensidade de imunomarcação nuclear, enquanto houve também uma diminuição na frequência percentual de células com imunomarcação nuclear de acordo com a progressão do melanoma comparando-se os casos menos com os mais agressivos. Cães com melanoma apresentaram níveis séricos aumentados de galectina-3 quando comparados a animais saudáveis, mostrando seu uso potencial como biomarcador em pacientes com melanoma.

TERMOS DE INDEXAÇÃO: Galectinas 1, galectina 3, melanoma, caninos, lectinas, neoplasia, imunoistoquímica, microambiente tumoral.

\section{INTRODUCTION}

Galectin plays a key role in tumor microenvironment, contributing to neoplastic transformation, neoplastic cell survival, angiogenesis and metastasis development (Liu \& Rabinovich 2005). Galectins are carbohydrate-binding proteins of the lectin family that are present in the nucleus, cytoplasm, cell surface and secreted by cells in several tissues. Galectin-1 (gal-1) and galectin-3 (gal-3) are strongly related to neoplastic progression and metastasis development (Barondes et al. 1994, Van den Brûle et al. 2002, Liu \& Rabinovich 2005).

Expression of gal-1 and gal-3 has been studied in different types of human tumors, such as breast cancer (Khaldoyanidi et al. 2003, Moreno et al. 2013, Simone et al. 2014), prostate carcinomas (Wang et al. 2009, Knapp et al. 2013, Compagno et al., 2014), glioma (BINH et al. 2013, Verschuere et al. 2014) and melanoma (Prieto et al. 2006, Mourad-Zeidan 2008, Lefranc et al. 2011, Mathieu et al. 2012, Brown et al. 2012, Borges et al. 2013), but there are few studies about galectin expression in different types of canine tumors (Woo et al. 2001, Johnson et al. 2007, Oliveira et al. 2014, Ribeiro et al. 2016, Vargas et al. 2018). These studies evaluated the expression of galectin-3 by the immunohistochemistry technique in gastric carcinoma, hemangiosarcoma, various canine tumors and mammary carcinomas respectively, showing the expression according to the different cell types present in these tumors and the difference between cell compartments.

Some studies have pointed out the use of galectins as biomarkers of tumor progression and as a prognostic factor in humans with cutaneous melanoma and hepatocellular carcinoma (Vereecken et al. 2005, Matsuda et al. 2008) and dogs with mammary carcinoma (Ribeiro et al. 2016). Serum gal-3 was measured prior to surgery and then one month and three months after tumor resection in dogs with mammary carcinoma (Ribeiro et al. 2016). The highest concentrations of gal-3 were detected one month after surgery in all patients and, in subsequent examination, only animals with metastasis had persistently increased levels of serum gal-3 (Ribeiro et al. 2016). Also, in canine mammary carcinomas, an increase in gal-3 expression by immunohistochemistry has been detected in intravascular neoplastic cells and metastatic cells in lymph nodes, suggesting that increased expression of gal-3 contributes to metastasis development (Oliveira et al. 2014). Even though progress has been made regarding mammary carcinomas, there is little information about galectin expression patterns in canine melanoma, which is just as aggressive, highly metastatic and difficult to treat.

Comprehensive studies about galectin expression patterns in canine melanoma have not been published, so the present study verified the expression patterns of galectin-1 and galectin-3 on melanoma samples and assessed serum concentration of galectin-3 in canine patients with naturallyoccurring melanoma.

\section{MATERIALS AND METHODS}

Case selection and samples. All animals were included in the study after owner's consent. The study was approved by the Ethics Committee on Animal Use (CEUA/FMVZ-USP) under protocol 4360110815. Tumor samples were collected prospectively from 54 canine patients with melanomas from several teaching veterinary hospitals and private clinics and six samples of canine melanocytoma obtained retrospectively from the Veterinary Pathology Service at the "Universidade de São Paulo" (USP). Of the melanoma patients, 24 animals were removed from the study due to the presence of other diseases, and 30 animals met the inclusion criteria. These animals had no other disease that could interfere with the study. Animals were staged at the pre-surgery with physical examination, complete blood count, complete serum biochemistry, triple thoracic radiographs views, abdominal ultrasound examination and echocardiogram. Tumor samples were fixed in 10\% formaldehyde for 48 hours and later included in paraffin blocks.

To analyze and compare gal-3 expression among samples, 4 groups were formed according to the degree of aggressiveness: melanocytoma $(\mathrm{M}, \mathrm{n}=6)$, non-metastatic melanoma (NM, $\mathrm{n}=9$ ), metastatic melanoma (MM, n=21). The metastatic lymph nodes (LN) were harvested from 9 of the patients from the MM group. The degree of aggressiveness was defined according to the progression of melanocytomas to melanomas and metastatic tissues and the groups represent different stages of disease evolution. Melanocytomas were considered the least aggressive tumors due to their benign behavior. Melanomas from non-metastatic patients (group NM) were considered less aggressive than melanomas from metastatic patients (group MM). LN groups of metastatic lymph nodes from patients in group MM were considered the most aggressive because they are metastatic tissues. Table 1 shows the epidemiological information regarding breed, age, sex, site of melanoma, pigmentation and aggressiveness.

Serum dosage of gal-3. Serum samples were collected from the same 30 melanoma-bearing dogs prior to excision of the neoplasia and kept under refrigeration at 2 to $8^{\circ} \mathrm{C}$ for 24 hours after collection. Serum samples were also collected from 10 animals considered clinically healthy after clinical examination, blood cell count and biochemical analyses (control group). All samples were stored at $-70^{\circ} \mathrm{C}$ until quantification of gal-3. Serum concentrations of gal-3 were determined using a commercial kit according to manufacturer's instructions (R\&D Systems-Quantikine ${ }^{\circledR}$ ELISA, Minneapolis/MN, USA).

Immunohistochemistry (IHC) for gal-1 and gal-3. Histological sections of tumor tissues ( $5 \mu \mathrm{m}$ width) were placed over silanized slides, then tissue melanin removal was performed as described (Silva et al. 2011). Slides were incubated for 12 to 24 hours at room 
temperature in TrisHCL buffer (pH 7.4, 0.2M) with 10\% hydrogen peroxide. Following dewaxing, antigen retrieval was carried out in a pascal pan (S2800, Dako Cytomation-Carpinteria, CA) for 19 minutes at $125^{\circ} \mathrm{C}$ temperature with citrate buffer (pH 6.0,10mM) and blocking endogenous peroxidase was achieved with $6 \%$ hydrogen peroxide for 30 minutes at room temperature. Anti-gal-1 antibody (Galectin-1/LGALS1-D608T- Cell Signaling) was incubated for 1 hour at $37^{\circ} \mathrm{C}$ at $1: 3000$ dilution in PBS with $3 \%$ BSA, and anti-gal-3 antibody (Galectin-3/LGALS3-D4I2R-Cell Signaling) was incubated overnight refrigerated in the 1:600 dilution in PBS with 1\% BSA. The detection system used was SuperPicture ${ }^{\mathrm{TM}}$ (Thermo Fisher Scientific, Waltham/MA, USA). Diaminobenzidine was used as chromogen and the sections were counterstained with Harris hematoxylin, mounted and assessed in an optical microscope.

Immunohistochemical analysis was performed by two evaluators on a Nikon microscope (model 80i) in 400x high power throughout the tumor. For gal-3, four scores were assigned according to the frequency of labeled cells: score $1=0-5 \%$ cells, score $2=6-25 \%$ cells, score $3=26-75 \%$, and score $4=>75 \%$ cells. Regarding the intensity of labeled cells, a scale from 1 to 3 was established: $1=$ weakly stained, 2 = moderately stained, and 3 = heavily stained. These parameters were analyzed separately for both nuclear labeling and cytoplasmic labeling and compared among the four groups formed. Since all samples were very homogeneous for gal-1 staining no score was assigned.

Western blot for gal-3. The validation of the human antibody used for canine galectin-3 was performed by using the western blot technique on five canine melanoma samples and two cell lines MeLn and CF41 (canine melanoma and one of canine mammary carcinoma, respectively).

Tumor samples were transported from the veterinary hospitals to our laboratory in refrigerated RPMI-1640 cell culture medium (Gibco, Thermo Fisher Scientific, Waltham/MA, USA). The tumors were fragmented and incubated with $1 \mathrm{mg} / \mathrm{mL}$ collagenase II (Gibco, Thermo Fisher Scientific, Waltham/MA, USA) in RPMI for 90 minutes in water bath at $37^{\circ} \mathrm{C}$ under constant magnetic stirring. Then, the solution was filtered using a nylon filter $(70 \mu \mathrm{m}$ - Cell Strainer, BD Biosciences). Cells were stored in cryoprotectant solution (fetal bovine serum, Sigma-Aldrich) with 10\% dimethyl sulfoxide (SigmaAldrich) and placed in liquid nitrogen. The next step was protein extraction from canine melanoma cells and two other cell lines used as controls: CF41.Mg (canine breast carcinoma - ATCC) and MeLn (melanoma cell line derived from a metastatic lymph node which was established in our laboratory and tested positive for MelanA

Table 1. Characterization of dogs with melanoma according to breed, age, sex, site of melanoma, degree of pigmentation, aggressiveness and site of metastasis

\begin{tabular}{|c|c|c|c|c|c|c|c|}
\hline Animal & Breed & $\begin{array}{c}\text { Age } \\
\text { (years) }\end{array}$ & Gender & Site of tumor & Pigmentation & Aggressiveness & Site of metastasis \\
\hline 1 & English Bulldog & 8 & Male & Digit & Melanic & MM & Lymph node \\
\hline 2 & Cocker Spaniel & 14 & Female & Oral & Melanic & NM & - \\
\hline 3 & Schnauzer & 12 & Female & Digit & Melanic & NM & - \\
\hline 4 & Poodle & 8 & Male & Skin & Melanic & MM & Lymph node \\
\hline 5 & Mixed breed & 10 & Male & Oral & Melanic & MM & Lymph node \\
\hline 6 & Chow & 8 & Male & Oral & Melanic & MM & Lymph node \\
\hline 7 & Golden Retriever & 9 & Male & Oral & Melanic & MM & Lymph node \\
\hline 8 & Mixed breed & 13 & Male & Oral & Melanic & NM & - \\
\hline 9 & Poodle & 10 & Male & Oral & Melanic & MM & Lymph node \\
\hline 10 & Labrador Retriever & 11 & Female & Oral & Melanic & MM & Lymph node, lung \\
\hline 11 & Yorkshire Terrier & 12 & Female & Oral & Amelanic & NM & - \\
\hline 12 & Dachshund & 12 & Female & Oral & Melanic & MM & Lymph node \\
\hline 13 & Cocker Spaniel & 12 & Female & Digit & Melanic & MM & Lymph node \\
\hline 14 & German Sheperd & 10 & Male & Oral & Melanic & MM & Lymph node \\
\hline 15 & Mixed breed & 15 & Female & Oral & Melanic & MM & Lymph node \\
\hline 16 & Yorkshire Terrier & 12 & Female & Oral & Melanic & NM & - \\
\hline 17 & Mixed breed & 13 & Male & Oral & Melanic & MM & Lymph node \\
\hline 18 & Poodle & 15 & Male & Oral & Melanic & MM & Lymph node \\
\hline 19 & Mixed breed & 13 & Male & Oral & Melanic & NM & - \\
\hline 20 & Mixed breed & 13 & Male & Oral & Amelanic & MM & Lymph node \\
\hline 21 & Golden Retriever & 1 & Female & Oral & Amelanic & NM & - \\
\hline 22 & Schnauzer & 11 & Female & Oral & Melanic & NM & - \\
\hline 23 & Dachshund & 14 & Female & Oral & Melanic & MM & Lymph node \\
\hline 24 & Mixed breed & 15 & Male & Oral & Melanic & NM & - \\
\hline 25 & Akita & 13 & Male & Oral & Melanic & MM & Lung \\
\hline 26 & Pug & 11 & Female & Oral & Amelanic & MM & Lymph node \\
\hline 27 & Poodle & 13 & Male & Oral & Melanic & MM & Lymph node \\
\hline 28 & Mixed breed & 12 & Male & Oral & Amelanic & MM & Lung \\
\hline 29 & Mixed breed & 17 & Male & Skin & Melanic & MM & Lymph node, lung \\
\hline 30 & Golden Retriever & 11 & Female & Oral & Amelanic & MM & Lymph node \\
\hline
\end{tabular}

$\mathrm{NM}=$ non-metastatic melanoma, $\mathrm{MM}=$ metastatic melanoma. 
and PNL2 (Giudice et al. 2010). Proteins were extracted using RIPA buffer (Sigma-Aldrich) with 1x protease and phosphatase inhibitors (Halt ${ }^{\mathrm{TM}}$ single-use cocktail, EDTA-free, 100x, Thermo Fisher Scientific, Waltham/MA, USA). Protein quantification was performed by Quick Start $^{\mathrm{TM}}$ Bradford Protein Assay (Bio-Rad).

Thirty micrograms total protein were resolved in $12 \%$ SDS-PAGE gels and run in standard PAGE running buffer for 90 minutes at 90V. Proteins were transferred to PDVF membranes in a Transblot Turbo $^{\mathrm{TM}}$ (Bio-Rad), standard 30-minute protocol, and the membranes were blocked with $5 \%$ bovine serum albumin fraction V (BSA, ICN Biomedicals) in Tris-buffered saline-Tween 20 (TBS-T) at room temperature for 1 hour. Gal-3 was detected using a human antigal-3 antibody (Galectin-3/LGALS3-D4I2R- Cell Signaling) 1:1000. Secondary anti-rabbit IgG antibody conjugated to HRP was then added at 1:50000 dilution (Bio-Rad). $\beta$-actin was used as loading control (monoclonal anti-mouse $\beta$-actin antibody (Sigma-Aldrich) 1:50000 dilution and anti-mouse IgG HRP 1:50000 dilution (BioRad). Membranes were visualized using ECL substrate (Clarity ${ }^{\mathrm{TM}}$, Bio-Rad) in the Bio-Rad ChemiDoc ${ }^{\circledR}$, and band intensity was quantified using Scion software.

Statistical analysis. Serum levels of gal-3 were compared between healthy and melanoma-bearing dogs using Student's t-test. Normality was assessed using the Shapiro-Wilk test. The Fisher's exact test was used in this study to identify differences in gal-3 immunohistochemistry staining scores between groups. The significance level was set at $p<0.05)$ and statistical analysis was performed using GraphPad Prism version 6 (San Diego/CA, USA).

\section{RESULTS}

\section{Epidemiological information}

In this study, the median age was 12 years (minimum value 1 and maximum value 17) and there was no gender prevalence (17 males and 13 female dogs). The number of animals and their proportion in relation to the racial definition, melanic and amelanotic form, anatomical location and staging are illustrated in Table 1. The control group for the serum dosage of gal-3 was formed by 10 dogs, 50\% male and $50 \%$ female. The median age was 9 years (minimum value 7 and maximum value 13). The patients had a predominance of melanotic $(80 \%)$ followed by $20 \%$ amelanotic tumors and the oral mucosa was the most common location for melanoma $(83 \%)$ followed by digit (10\%) and skin (7\%).

\section{Expression of gal-1}

The pattern of gal-1 expression in the tumor samples was predominantly cytoplasmic. Frequency of labeled cells was predominantly greater than 75\% (Fig.1).

\section{Expression of gal-3}

All tumor samples expressed immunoreactivity for gal-3 and their expression pattern was analyzed according to the scores assigned for cytoplasmic and nuclear immunolabeling intensity and according to the frequency of immunolabeled cells. This expression was compared among study groups: melanocytoma (M, n=6) (Fig.2A), non-metastatic melanoma (NM, n=9) (Fig.2B), metastatic melanoma (MM, n=21) (Fig.2C) and metastatic lymph nodes (LN, n=9) (Fig.2D). Fisher's exact test was used to compare intensity of both cytoplasmic and nuclear immunolabeling (Table 2 and 3) and frequency of

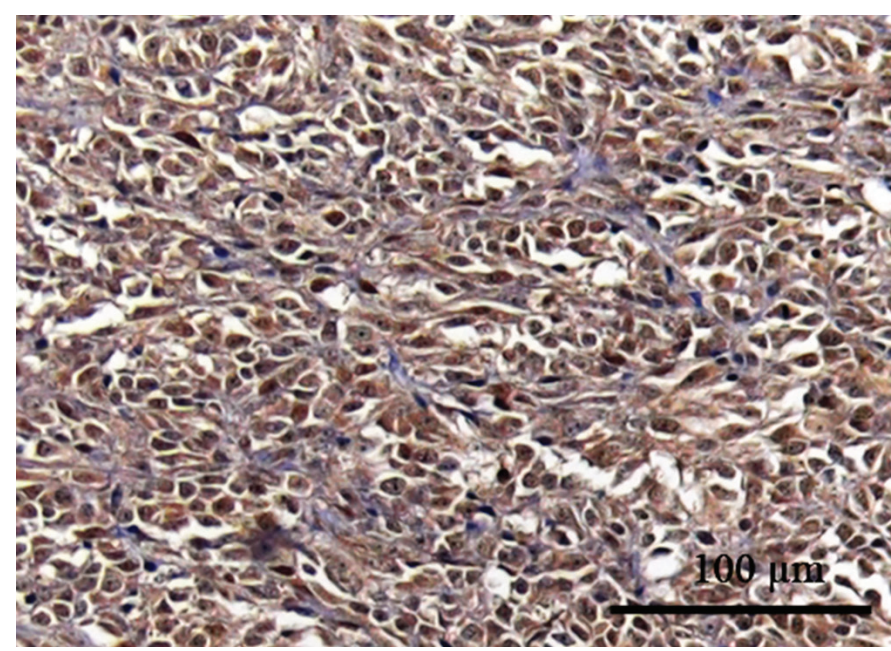

Fig.1. Canine melanoma immunolabelled for galectin-1. Positive staining in brown and counter-staining in Harris haematoxylin, obj.20x.

positive cells for both cytoplasmic and nuclear immunolabeling (Table 4 and 5).

\section{Serum gal-3}

Gal-3 serum levels of melanoma-bearing dogs (mean = $14.55 \pm 3.48 \mathrm{ng} / \mathrm{mL}$ ) were compared with healthy animals (mean $=10.76 \pm 2.23 \mathrm{ng} / \mathrm{mL}$ ) by parametric Student's t-test and there was a statistically significant difference ( $p$-value $=0.0027$ ) (Fig.3).

\section{Western Blot for gal-3}

Validation of human antibody to gal-3 was performed using western blot. The blot shows that human anti-gal-3 antibody was able to detect gal-3 in protein samples from five canine tumors used in this study, as well as in canine tumor cell lines described. Additionally, gal-3 expression was variable among cell lines and tumor samples within the same aggressiveness degree (Fig.4).

\section{DISCUSSION}

This is the first prospective study that evaluated expression patterns of gal- 1 and gal-3 in canine melanomas of different degrees of aggressiveness and compared serum levels of gal3 in melanoma-bearing dogs with healthy dogs. It has been increasingly recognized that galectins play an important role in modulating tumor cell proliferation and evolution by their interaction with the proteins encoded by the Ras oncogene that control cell proliferation, differentiation and survival (Paz et al. 2001).

In this study, the expression of gal-1 in tumor samples was predominantly cytoplasmic, since we observed more than $75 \%$ of immunolabeled cells in the majority of samples. The decision to not perform a semi-quantitative analysis on gal-1 expression was determined because tumor samples showed a very homogeneous expression pattern in frequency and a small variation in stain intensity. In human medicine, cytoplasmic expression of gal-1 can contribute to the transformation of tumor cells by interaction with proteins encoded by the Ras oncogene (Paz et al. 2001). Gal-1 can also be associated with angiogenesis, metastasis development by mechanisms of cell adhesion, 

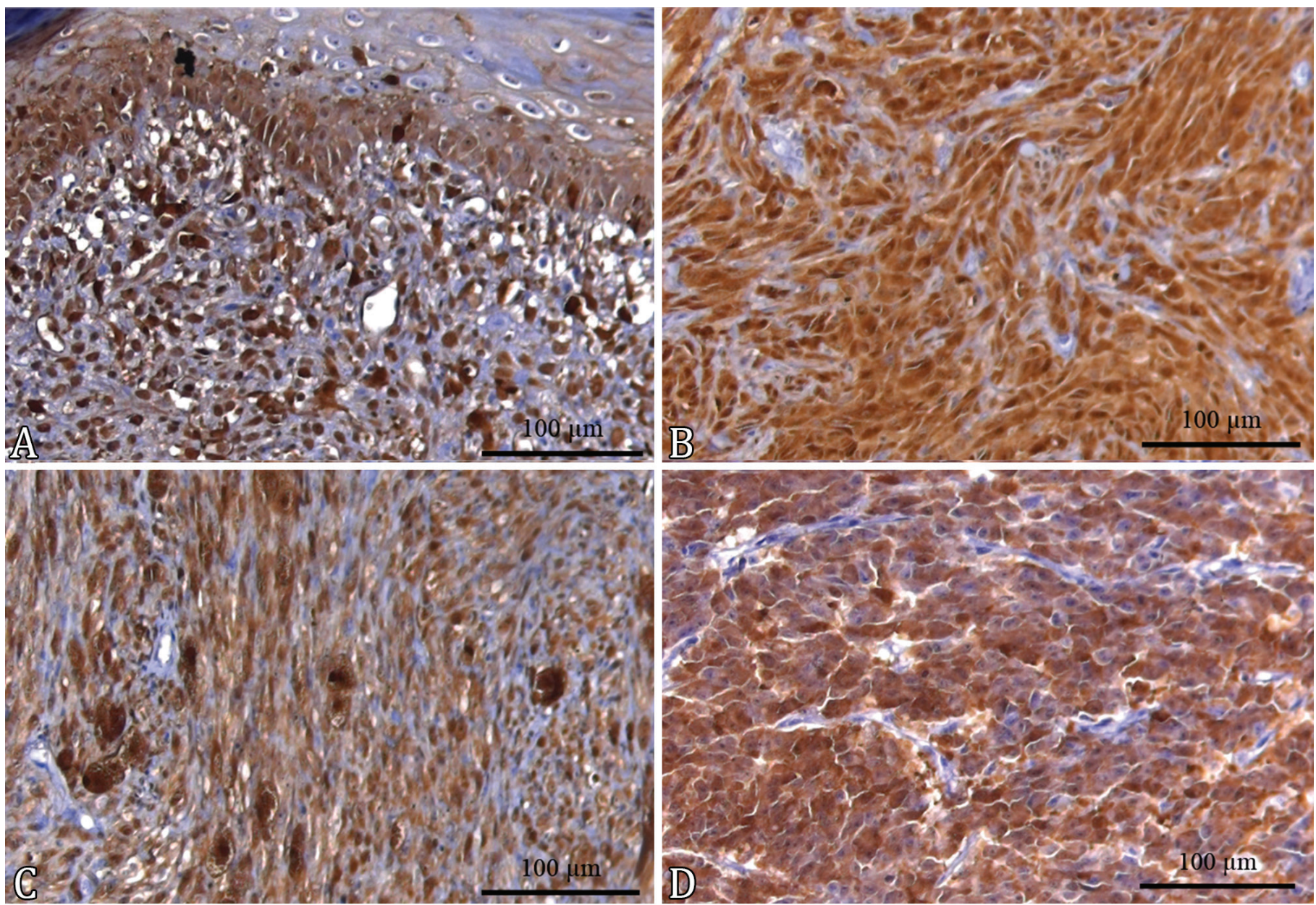

Fig.2. Canine melanoma according degree of aggressiveness immulabelled for galectin-3 (gal-3). (A) Canine melanocytoma immunolabelled for gal-3, cytoplasmic immunolabeling intensity score 3, cytoplasmic immunolabeling frequency score 3, nuclear immunolabeling intensity score 3 and nuclear immunolabeling frequency score 3. (B) Canine non-metastatic melanoma immunolabelled for gal-3, cytoplasmic immunolabeling intensity score 2, cytoplasmic immunolabeling frequency score 4, nuclear immunolabeling intensity score 2 and nuclear immunolabeling frequency score 3. (C) Canine metastatic melanoma immunolabelled for gal-3, cytoplasmic immunolabeling intensity score 2, cytoplasmic immunolabeling frequency score 4, nuclear immunolabeling intensity score 3 and nuclear immunolabeling frequency score 3. (D) Canine metastatic melanoma lymph nodes immunolabelled for gal-3, cytoplasmic immunolabeling intensity score 2, cytoplasmic immunolabeling frequency score 4, nuclear immunolabeling intensity score 2 and nuclear immunolabeling frequency score 3. Positive staining in brown and counter-staining in Harris haematoxylin, obj.20x.

Table 2. Contingency table with number of animals (n) and frequency of distribution in percentage for the different cytoplasmic immunolabeling intensity scores of gal-3 in relation to $\mathrm{M}, \mathrm{NM}, \mathrm{MM}$ and $\mathrm{LN}$ comparison groups

\begin{tabular}{ccccccc}
\hline Cytoplasmic intensity & M (n) $\%$ & NM (n) $\%$ & MM (n) $\%$ & LN (n) $\%$ & Total & $P$-value \\
\hline 1 & (2) 33 & (1) 11 & (5) 24 & (1) 11 & $9<0.0001$ \\
2 & (3) 50 & (7) 78 & (14) 67 & (8) 89 & 32 & (1) 0 \\
3 & (1) 17 & (1) 11 & (2) 10 & (0) 0 & 4
\end{tabular}

$\overline{\mathrm{M}=\text { melanocytoma, } \mathrm{NM}=\text { non-metastatic melanoma }}, \mathrm{MM}=$ metastatic melanoma, $\mathrm{LN}=$ metastatic lymph nodes.

Table3. Contingency table with number of animals (n) and frequency of distribution in percentage for the different gal-3 nuclear immunolabeling intensity scores compared to $\mathrm{M}, \mathrm{NM}, \mathrm{MM}$ and LN comparison groups

\begin{tabular}{|c|c|c|c|c|c|c|}
\hline Nuclear intensity & $\mathrm{M}(\mathrm{n}) \%$ & NM (n) \% & MM (n) \% & LN (n) \% & Total & $P$-value \\
\hline 1 & (0) 0 & (0) 0 & (0) 0 & (0) 0 & 0 & $P<0.0001$ \\
\hline 2 & (5) 83 & (4) 44 & (10) 48 & (4) 44 & 23 & \\
\hline 3 & (1) 17 & (5) 56 & (11) 52 & (5) 56 & 22 & \\
\hline
\end{tabular}

$\overline{\mathrm{M}=\text { melanocytoma, } \mathrm{NM}=\text { non-metastatic melanoma }}, \mathrm{MM}=$ metastatic melanoma, $\mathrm{LN}=$ metastatic lymph nodes. 
Table 4. Contingency table with number of animals (n) and frequency of distribution in percentage for the different cytoplasmic immunolabeling frequency scores of gal-3 compared to $\mathrm{M}, \mathrm{NM}, \mathrm{MM}$ and LN comparison groups

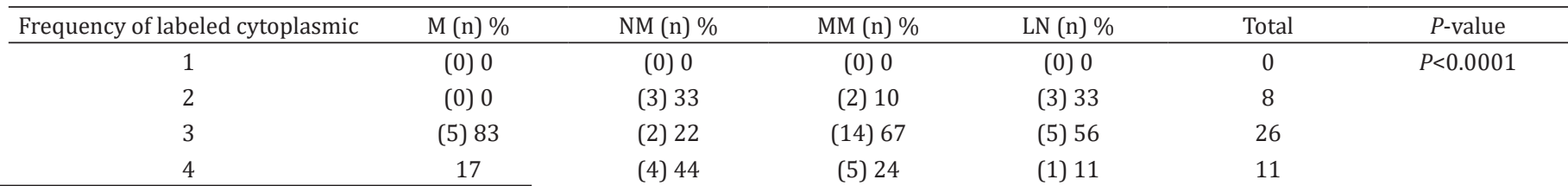

$\mathrm{M}=$ melanocytoma, $\mathrm{NM}=$ non-metastatic melanoma, $\mathrm{MM}=$ metastatic melanoma, $\mathrm{LN}=$ metastatic lymph nodes.

Table 5. Contingency table with number of animals (n) and frequency of distribution in percentage for the different gal-3 nuclear immunolabelling frequency scores compared to M, NM, MM and LN comparison groups

\begin{tabular}{|c|c|c|c|c|c|c|}
\hline Frequency of labeled nuclear & M (n) \% & NM (n) \% & MM (n) \% & LN (n) \% & Total & $P$-value \\
\hline 1 & (0) 0 & (0) 0 & (0) 0 & (0) 0 & 0 & $P<0.0001$ \\
\hline 2 & (0) 0 & (4) 44 & (5) 24 & (5) 56 & 14 & \\
\hline 3 & (6) 100 & (5) 56 & (16) 76 & (4) 44 & 31 & \\
\hline
\end{tabular}

$\overline{\mathrm{M}}=$ melanocytoma, $\mathrm{NM}=$ non-metastatic melanoma, $\mathrm{MM}=$ metastatic melanoma, $\mathrm{LN}=$ metastatic lymph nodes.

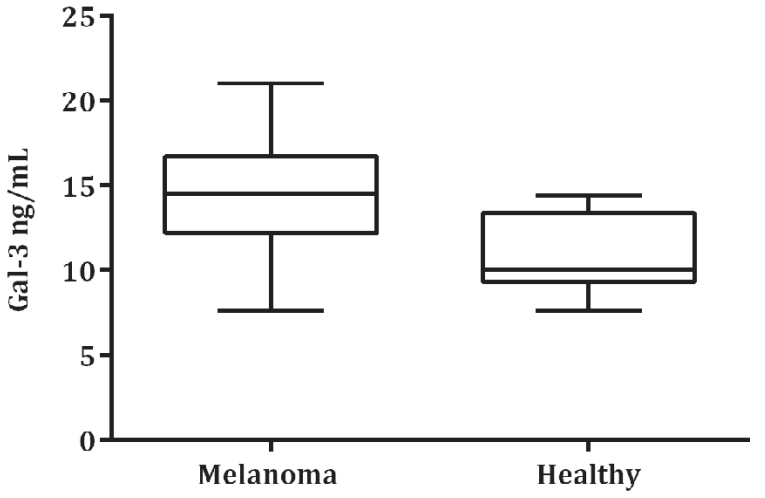

Fig.3. Mean serum concentrations of galectin-3 from melanomabearing dogs and healthy dogs. Box plots $p<0.05$.

regulating immune evasion mechanisms, and immune system evasion that occurs due to Tlymphocyte turnout (Rabinovich 2005, Camby et al. 2006). In addition, gal-1 expression in human melanomas has been correlated with increased tumor resistance to radiotherapy and chemotherapy treatments, due to modulation of angiogenesis and immunosuppressive cells infiltrating the tumor microenvironment (Brown et al. 2012, Borges et al. 2013). Gal-1 expression was also reported in canine mammary tumors, in which an increased staining in tumor and stromal cells (Oliveira et al. 2014) was observed. Even though gal-1 may play a significant role in tumor regulation and might be a novel therapeutic target for canine melanoma, further studies are necessary to elucidate the underlying mechanisms involved in tumor development.

In contrast to gal-1, expression of gal- 3 was observed in a heterogeneous cellular location among groups, suggesting a shift in its pattern during melanoma progression, since our immunohistochemistry slides were analyzed according to the degree of aggressiveness and not by clinical stage (Owen 1980).

Surprisingly, no sample of the LN group fell under the heavily stained category, suggesting that cytoplasmic intensity of gal-3 expression significantly decreases throughout progression of melanoma and metastasis formation. Regarding the frequency of cytoplasmic immunolabeling, a decrease of labeled cells in the MM and LN groups was observed when compared to the

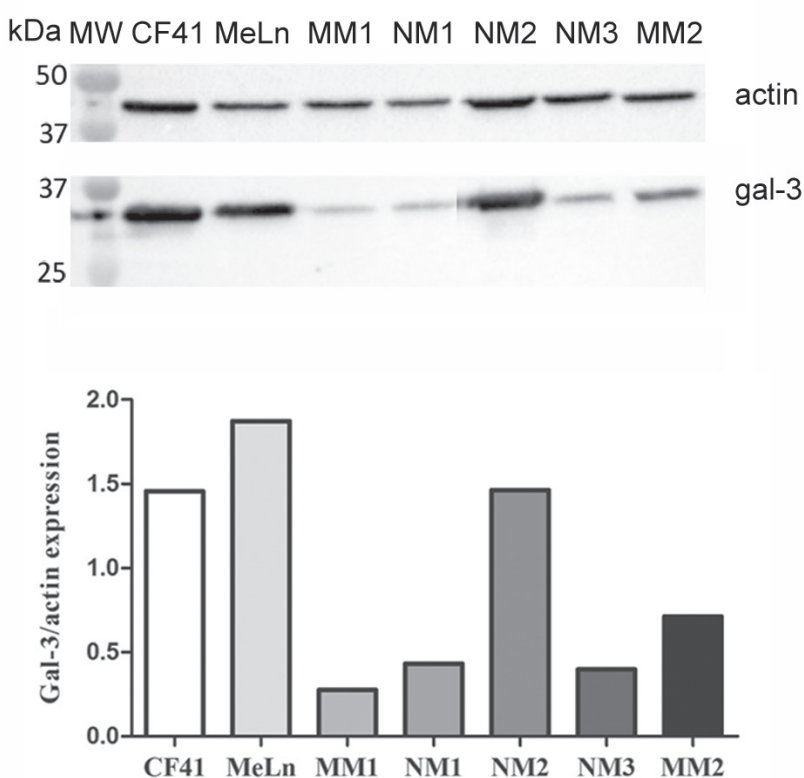

Fig.4. Western blot analysis of galectin-3 (gal-3) expression in canine primary melanomas. Blots were exposed to anti-gal-3 and antiactin antibodies. For each sample, gal-3 protein bands density was quantified and relativized to their respective beta-actin loading control. Canine mammary gland carcinoma cell line (CF41), canine lymph node metastatic melanoma cell line (MeLn), non-metastatic melanoma (NM), metastatic melanoma (MM).

$\mathrm{NM}$ and $\mathrm{M}$ groups, showing that there is a negative correlation between cytoplasmic staining of gal-3 and melanoma progression. According to Brown et al. (2012), high expression of gal-3 in early primary melanomas may contribute to resistance to apoptosis of these cells and metalloproteinases that are released by these cells during melanoma progression use gal-3 as a substrate, causing depletion of intracellular stocks (Brown et al. 2012). Our findings corroborate the hypothesis of Brown et al. (2012), where the depletion of intracellular gal-3 stores in melanoma progression was associated with an unfavorable prognosis and increased risk of developing metastasis (Brown et al. 2012). 
Regarding nuclear immunolabeling intensity, a higher expression of gal-3 was observed in more aggressive tumors in NM, MM, LN groups when compared to benign tumors in group M. These findings corroborate those of MouradZeidan (2008), who showed that metastatic lesions in human melanoma patients display high nuclear expression of gal-3 (Mourad-Zeidan 2008). Concomitant to this increase in nuclear immunolabeling intensity, a reduction in frequency of nuclear immunolabeled cells was observed in samples of the most aggressive tumors of NM, MM, LN groups when compared to benign tumors of group M. Brown et al. (2012) showed that human patients with melanoma presented worse prognosis when nuclear gal-3 expression was less frequent (Brown et al. 2012). Prieto et al. (2006) found opposing results when comparing benign neoplasms with cutaneous melanomas in different stages of evolution in human patients since he suggested that, as melanoma progresses, there is an increase in gal-3 expression (Prieto et al. 2006). This disagreement of results can be explained by the difference between the methodologies, especially in relation to the antibody used, since gal-3 can be cleaved by extracellular matrix metalloproteinases.

The present study suggests that gal-3 expression in canine melanomas is similar to gal-3 expression in human cutaneous melanomas as noted by previous studies, in which, during melanoma progression, there was a decrease in expression of gal-3 when comparing benign melanocytic lesions with melanomas at degrees of aggressiveness.

Serum gal-3 has been proposed as a prognostic biomarker in humans with skin melanoma (Vereecken et al. 2005). In our study, dogs with melanoma had a higher serum concentration of gal- 3 when compared to healthy dogs. This data is in accordance with Vereecken et al. (2005), which found increased serum gal-3 concentrations in human patients with skin melanoma, suggesting that neoplastic cells are responsible for releasing gal-3 in the blood (Vereecken et al. 2005). Serum concentration of gal-3 could also be used to predict the presence of metastasis in dogs, since Ribeiro et al. (2016) showed that only mammary carcinoma patients that developed metastasis continued to have elevated serum gal-3 concentrations (Ribeiro et al. 2016) after mastectomy. In the present study, it was impossible to evaluate the potential of serum concentration of gal-3 as a prognostic factor and predictor of metastasis, because blood samples were collected at only one time point (before tumor removal).

We demonstrated that human anti-gal-3 antibody used in immunohistochemistry assays was detected in western blots and the protein possesses the expected molecular weight. This analysis was performed only in a few samples to confirm the specificity of antibody, so it was not possible to perform an extensive comparison between samples.

In human medicine, gal-3 inhibitors are being studied. These molecules are modified citrus pectin which can compete with glycans and block gal-3, mediating cell survival (Glinsky \& Raz 2009, Demotte et al. 2014). Therefore, further studies are needed to better understand the contribution of these molecules to the development of canine melanoma and to investigate galectins as potential therapeutic targets.

\section{CONCLUSIONS}

Expression pattern of gal-1 in canine melanoma was predominantly cytoplasmic regardless of the degree of aggressiveness.

Our findings suggest that during canine melanoma progression, there was a decrease in expression of gal-3 when comparing benign melanocytic lesions with melanomas at degrees of agressiveness.

Dogs with spontaneous melanoma had increased serum levels of gal-3 before the excision of the neoplasia when compared to the clinically healthy animals, indicating a potential use as a monitoring and prognostic tool in patients with melanoma.

Acknowledgements.- This work is based on a Master thesis supported by "Coordenação de Aperfeiçoamento de Pessoal de Nível Superior" (CAPES) and "Fundação de Apoio à Pesquisa do Estado de São Paulo" (FAPESP, grant no. 2015/14758-8). Special thanks to clinical veterinarians who provided samples for this work.

Conflict of interest statement.- There are no conflicts of interest.

\section{REFERENCES}

Barondes S.H., Cooper D.N.W., Gitts M.A. \& Lefflerm H. 1994. Galectins: structure and function of a large family of animal lectins. J. Biol. Chem. 269(33):20807-20810. <PMid:8063692>

Binh N.H., Satoh K., Kobayashi K., Takamatsu M., Hatano Y., Hirata A., Tomita H., Kuno T. \& Hara A. 2013. Galectin-3 in preneoplastic lesions of glioma. J. Neurooncol.111(2):123-132. <https://dx.doi.org/10.1007/s11060-012-1005-2> <PMid:23179497>

Borges B.E.,Teixeira V.R., Appel M.H., Steclan C.A., Rigo F., Filipak Neto F., Da Costa Ferreira A.M., Chammas R., Zanata S.M. \& Nakao L.S. 2013. De novo galectin-3 expression influences the response of melanoma cells to isatinSchiff base copper (II) complex-induced oxidative stimulus. Chem. Biol. Interact. 206(1):37-46. <https://dx.doi.org/10.1016/j.cbi.2013.08.005> <PMid:23994248>

Brown E.R., Doig T., Anderson N., Brenn T., Doherty V., Xu Y., Bartlett J.M., Smyth J.F. \& Melton D.W. 2012. Association of galectin-3 expression with melanoma progression and prognosis. Eur. J. Cancer 48(6):865-874. <https://dx.doi.org/10.1016/j.ejca.2011.09.003> <PMid:22071132>

Camby I., Le Mercier M., Lefranc F. \& Kiss R. 2006. Galectin-1: a small protein with major functions. Glycobiology 16(11):137R-157R. <https://dx.doi. org/10.1093/glycob/cwl025><PMid:16840800>

Compagno D., Gentilini L.D., Jaworski F.M., Pérez I.G., Contrufo G. \& Laderach D.J. 2014. Glycans and galectins in prostate cancer biology, angiogenesis and metastasis. Glycobiology 24(10):899-906. <https://dx.doi.org/10.1093/ glycob/cwu055><PMid:24939371>

Demotte N., Bigirimana R., Wieërs G., Stroobant V., Squifflet J.L., Carrasco J., Thielemans K., Baurain J.F., Van der Smissen P., Courtoy P.J. \& van der Bruggen P. 2014. A short treatment with galactomannan GM-CT-01 corretcs the functions of freshly isolated human tumor-infiltrating lymphocytes. Clin. Cancer Res. 20(7):1823-1833. <https://dx.doi.org/10.1158/10780432.CCR-13-2459><PMid:24526733>

Giudice C., Ceciliani F., Rondena M., Stefanello D. \& Grieco V. 2010. Immunohistochemical investigation of PNL2 reactivity of canine melanocytic neoplasms and comparison with Melan A. J. Vet. Diagn. Invest. 22(3):389-394. <https://dx.doi.org/10.1177/104063871002200307><PMid:20453212>

Glinsky V.V. \& Raz A. 2009. Modified citrus pectin anti-metastatic properties: one bullet, multiple targets. Carbohydr. Res. 344(14):1788-1791. <https://dx.doi.org/10.1016/j.carres.2008.08.038> <PMid:19061992> 
Johnson K.D., Glinskii O.V., Mossineb V.V., Turk J.R., Mawhinneyb T.P., Anthony D.C., Henry C.J., Huxleyz V.H., Glinsky G.V., Pienta K.J., Razbb A. \& Glinsky V.V. 2007. Galectin-3 as a potential therapeutic target in tumors arising from malignant endothelia. Neoplasia 9(8):662-670. <https://dx.doi. org/10.1593/neo.07433><PMid:17786185>

Khaldoyanidi S.K., Glinsky V.V., Sikora L., Glinskii A.B., Mossine V.V., Quinn T.P., Glinsky G.V. \& Sriramarao P. 2003. MDA-MB-435 Human breast carcinoma cell homo- and heterotypic adhesion under flow conditions is mediated in part by Thomsen-Friedenreich antigen-galectin-3 interactions. J. Biol. Chem. 278(6):4127-4134. <https://dx.doi.org/10.1074/jbc.M209590200> <PMid:12438311>

Knapp J.S., Lokeshwar S.D., Vogel U., Hennenlotter J., Schwentner C., Kramer M.W., Stenzl A. \& Merseburger A.S. 2013. Galectin-3 expression in prostate cancer and benign prostate tissues: correlation with biochemical recurrence. World J. Urol. 31(2):351-358. <https://dx.doi.org/10.1007/s00345-012-0925-y> <PMid:22892876>

Lefranc F., Mathieu V. \& Kiss R. 2011. Galectin-1-mediated biochemical controls of melanoma and glioma aggressive behavior. World J. Biol. Chem. 2(9):193201. <https://dx.doi.org/10.4331/wjbc.v2.i9.193><PMid:21949569>

Liu F.T. \& Rabinovich G.A. 2005. Galectins as modulators of tumor progression. Nat. Rev. Cancer 5(1):29-41. <https://dx.doi.org/10.1038/nrc1527> <PMid:15630413>

Mathieu V., De Lassalle E.M., Toelen J., Mohr T., Bellahcène A., Van Goietsenoven G., Verschuere T., Bouzin C., Debyser Z., De Vleeschouwer S., Van Gool S., Poirier F., Castronovo V., Kiss R. \& Feron O. 2012. Galectin-1 in melanoma biology and related neo-angiogenesis processes. J. Invest. Dermatol. 132(9):22452254. <https://dx.doi.org/10.1038/jid.2012.142> <PMid:22622427>

Matsuda Y., Yamagiwa Y., Fukushima K., Ueno Y. \& Shimosegawa T. 2008. Expression of galectin-3 involved in prognosis of patients with hepatocellular carcinoma. Hepatol. Res. 38(11):1098-1111. <https://dx.doi.org/10.1111/ j.1872-034X.2008.00387.x><PMid:18684128>

Moreno T.D., Croci D.O., Cerliani J.P., Martinez-Allo V.C., Dergan-Dylon S., MéndezHuergo S.P., Stupirski J. C., Mazal D., Osinaga E., Toscano M.A., Sundblad V., Rabinovich G.A. \& Salatino M. 2013. Targeting galectin-1 overcomes breast cancer-associated immunosuppression and prevents metastatic disease. Cancer Res. 73(3):1107-1117. <https://dx.doi.org/10.1158/0008-5472. CAN-12-2418><PMid:23204230>

Mourad-Zeidan A.A. 2008. Role of galectin-3 in melanoma progression. Doctoral Dissertation, Faculty of Medicine, Ludwig-Maximilians-University, Munich. 164p.

Oliveira J.T., De Matos A.J., Barros R., Ribeiro C., Chen A., Hespanhol V., Rutteman G.R. \& Gärtner F. 2014. Differential expression of galectin-1 and galectin-3 in canine non-malignant and malignant mammary tissues and in progression to metastasis in mammary tumors. Anticancer Res. 34(5):2211-2222. <PMid:24778023>

Owen L.N. 1980. TNM classification of tumours in domestic animals. Veterinary Public Health Unit, WHO Collaborating Center for Comparative Oncology, World Health Organization, Genebra.
Paz A., Haklai R., Elad-Sfadi G., Ballan E. \& Kloog Y. 2001. Galectin-1 binds oncogenic H-Ras to mediate Ras membrane anchorage and cell transformation. Oncogene 20(51):7486-7493. <https://dx.doi.org/10.1038/sj.onc.1204950> $<$ PMid:11709720>

Prieto V.G., Mourad-Zeidan A.A., Melnikova V., Johnson M.M., Lopez A., Diwan AH., Lazar A.J., Shen S.S., Zhang P.S., Reed J.A., Gershenwald J.E., Raz A. \& Bar-Eli M. 2006. Galectin-3 expression is associated with tumor progression and pattern of sun exposure in melanoma. Clin. Cancer Res. 12(22):6709-6715. <https://dx.doi.org/10.1158/1078-0432.CCR-06-0758> $<$ PMid:17121890>

Rabinovich G.A. 2005. Galectin-1 as a potencial cancer target. Brit. J. Cancer 92(7):1188-1192. <https://dx.doi.org/10.1038/sj.bjc.6602493> <PMid:15785741>

Ribeiro C., Santos M.S., De Matos A.J., Barros R., Gärtner F., Rutteman G.R. \& De Oliveira J.T. 2016. Serum galectin-3 levels in dogs with metastatic and non-metastatic mammary tumors. In Vivo 30(1):13-16. <PMid:26709123>

Silva A.P., Silva R.G., Cogliati B., Dias A.S.M., Le Bas A.E. \& Hernandez-Blazquez F.J. 2011. Bleaching of melanin in the epidermis of South American fur seal and its application on enzyme immunohistochemistry. Pesq. Vet. Bras. 31(3):267-270.<https://dx.doi.org/10.1590/S0100-736X2011000300014>

Simone G., Malara N., Trunzo V., Renne M., Perozziello G., Di Fabrizio E. \& Manz A. 2014. Galectin-3 coats the membrane of breast cells and makes a signature of tumours. Mol. Biosyst. 10(2):258-265. <https://dx.doi. org/10.1039/c3mb70359b $><$ PMid:24281352>

Van Den Brûle F., Califice S. \& Castronovo V. 2002. Expression of galectins in cancer: a critical review. Glicoconj. J. 19(7/9):537-542. <https://dx.doi. org/10.1023/B:GLYC.0000014083.48508.6a ><PMid:14758077>

Vargas T.H.M., Pulz L.H. \& Strefezzi R.F. 2018. Immunohistochemical expression of Galectin-3 in canine tumors. Braz. J. Vet. Pathol. 11(1):1-6. <https://dx.doi.org/10.24070/bjvp.1983-0246.v11i1p1-6>

Vereecken P., Zouaoui Boudjeltia K., Debray C., Awada A., Legssyer I., Sales F., Petein M., Vanhaeverbeek M., Ghanem G. \& Heenem M. 2005. High serum galectin-3 in advanced melanoma: preliminary results. Clin. Exp. Dermatol. 31(1):105-109. <https://dx.doi.org/10.1111/j.1365-2230.2005.01992.x> <PMid:16309497>

Verschuere T., Toelen J., Maes W., Poirier F., Boon L., Tousseyn T., Mathivet T., Gerhardt H., Mathieu V., Kiss R., Lefranc F., Van Gool S.W. \& De Vleeschouwer S. 2014. Glioma-derived galectin-1 regulates innate and adaptive antitumor immunity. Int. J. Cancer. 134(4):873-884. <https://dx.doi.org/10.1002/ ijc.28426> <PMid:23929302>

Wang Y., Nangia-Makker P., Tait L., Balan V., Hogan V., Pienta K.J. \& Raz A. 2009. Regulation of prostate cancer progression by galectin-3. Am. J. Pathol. 174(4):1515-1523. <https://dx.doi.org/10.2353/ajpath.2009.080816> $<$ PMid:19286570>

Woo H.J., Joo H.G., Song S.W., Sohn Y.S. \& Chae C. 2001.Immunohistochemical detection of galectin-3 in canine gastric carcinomas. J. Comp. Pathol.124(2/3):216-218. <https://dx.doi.org/10.1053/jcpa.2000.0442> $<$ PMid:11222020> 